\title{
Biochemical study of striped catfish Pangasianodon hypophthalmus broodstock induced by PMSG hormone + antidopamine and turmeric addition
}

\section{Kajian biokimia induk ikan patin yang diberi hormon PMSG dan antidopamin ditambah kunyit}

\author{
Harton Arfah ${ }^{1 *}$, Agus Oman Sudrajat ${ }^{1}$, Muhammad Agus Suprayudi', Muhammad \\ Zairin $\mathbf{J r}^{1}$ \\ 'Department of Aquaculture, Faculty of Fisheries and Marine Science, Bogor Agricultural University, Dramaga, \\ Bogor, West Java, Indonesia 16680 \\ *Corresponding author: hartonarfah@yahoo.com
}

(Received October 10, 2017; Accepted July 30, 2018)

\begin{abstract}
This study aimed to evaluate biochemical changes (cholesterol, triglyceride, HDL, LDL, glucose, and plasma protein) on striped catfish Pangasianodon hypophthalmus broodstock induced with PMSG hormone and turmeric addition. An observation was also done to blood glycogen content. The striped catfish broodstock was fed on commercial feed without any addition (control) and with turmeric addition ( $\mathrm{HKu}$ ). In control treatment, there was a decreasing on cholesterol, meanwhile, the triglyceride (TG) value was increased. The HDL concentration was decreased in $2^{\text {nd }}$ sampling and increased in $4^{\text {th }}$ sampling. In $1^{\text {st }}$ until $4^{\text {th }}$ sampling, glucose was quite stable, while LDL was on extremely low concentration. In HKu treatment, the cholesterol value was higher than the control treatment. The TG concentration also higher than control in $3^{\text {rd }}$ sampling and decreased in $4^{\text {th }}$ sampling. The HDL concentration was increased and higher than the control treatment, while LDL concentration was lower. The liver glycogen content on the control and HKu treatment were $0.015(\mathrm{mg} / 100 \mathrm{~mL})$ and $0.181(\mathrm{mg} / 100 \mathrm{~mL})$ respectively; while in the flesh of the control and HKu treatment were $0.76(\mathrm{mg} / 100 \mathrm{~mL})$ and $1.19(\mathrm{mg} / 100 \mathrm{~mL})$ respectively; and in the gonad of control and HKu treatment were $0.10(\mathrm{mg} / 100 \mathrm{~mL})$ and $0.70(\mathrm{mg} / 100 \mathrm{~mL})$ respectively. It was shown that the glycogen content in the liver, flesh, and gonad on experimental fish was higher than control treatment.
\end{abstract}

Keywords : biochemistry, hormone, turmeric, channel catfish, reproduction

\begin{abstract}
ABSTRAK
Penelitian ini bertujuan untuk mengaji perubahan biokimia (kolesterol, trigliserida, HDL, LDL, glukosa dan protein plasma) pada induk ikan patin Pangasianodon hypophthalmus yang diberi perlakuan hormon PMSG dan kunyit. Pengamatan juga dilakukan terhadap glikogen dalam darah induk patin. Induk ikan patin diberi pakan tanpa penambahan kunyit (kontrol) dan pakan yang diberi kunyit (HKu). Hasil penelitian pada kontrol menunjukkan adanya penurunan kolesterol, sedangkan pada trigliserida (TG) mengalami peningkatan. HDL menurun pada sampling ke-2 dan meningkat pada sampling ke-4. Sementara itu, pada LDL rendah sekali dan pada glukosa terlihat stabil dari sampling ke-1 sampai ke-4. Pada perlakuan HKu terlihat bahwa pada kolesterol menghasilkan nilai lebih tinggi dibanding kontrol. Pada TG terlihat juga nilai lebih tinggi dibanding kontrol pada sampling ke-3 dan menurun pada sampling ke-4. Konsentrasi HDL meningkat dan lebih tinggi dibanding kontrol, sedangkan nilai LDL lebih rendah. Data yang diperoleh pada kadar glikogen hati perlakuan kontrol adalah 0,015 (mg/100 mL) dan HKu 0,181 (mg/100 mL); sedangkan pada daging kontrol sebesar 0,76 (mg/100 mL) dan HKu 1,19 (mg/100 $\mathrm{mL})$; ); serta gonad kontrol 0,10 (mg/100 mL) dan HKu 0,70 (mg/100 mL). Hal ini menunjukkan kadar glikogen pada hati, daging, dan gonad ikan yang diberi perlakuan bernilai lebih tinggi dibanding kontrol.
\end{abstract}




\section{INTRODUCTION}

Striped catfish Pangasianodon hypophthalmus is one of the farmed freshwater species in Indonesia. The rapid development of striped catfish aquaculture tends to increase the production target. This issue has to be followed by an adequate seeds supply. According to histology analysis, the development of oocyte in striped catfish takes approximately 18 weeks in a culture tank with sufficient feed. Kabir et al. (2012) described a beneficial information about the oocyte development and biological reproduction in striped catfish.

According to Forlano (2007) and Phodorec et al. (2016), dopamine play an essential role in gonadal maturation. An inhibitor compound, dopamine, causes signal inhibition in secretion of pituitary gonadotropin (Sudrajat et al., 2014). PMSG (pregnant mare serum gonadotropin) hormone utilization together with anti-dopamine (domperidone and pimozide) is more effective to induce gonadal maturation in various fish species, such as common carp and catfish (Sharaf, 2011), Redfin (Islami et al., 2017), and eel (Ahlina et al., 2017). Nugraha (2014) stated that supplmentation of PMSG $(0.25 \mathrm{mg} / \mathrm{kg})$ plus anti-dopamine $(0.01$ $\mathrm{mg} / \mathrm{kg}$ ) through feed was able to increase gonadal maturation in striped catfish.

Turmeric has a high content of phytoestrogen and it is acknowledged to support liver function by accelerating liver cell regeneration and protect it from any toxic (Hwa-Young et al., 2016). Turmeric is also able to improve the performance of digestion organ (Mahmoud et al., 2014; Thongon et al., 2017). Polipoch et al. (2014) stated that curcumin is a hepatoprotector compound so that it will protect liver cell structure. Turmeric flour is a curcumin compound which also acts as an antioxidant and plays a role to repair body tissues, such as liver and oviduct (Alinezhad, 2017; Kyung et al., 2018). Feed enrichment with turmeric flour is effective to induce gonadal maturation, particularly outside the spawning season (Tahapari \& Dewi, 2015).

Cholesterol is a compound that directly related to reproduction and gonadal maturation (Hiramatsu et al. 2015; Shankar \& Kulkarni, 2007). Cholesterol is a precursor for various types of steroid hormone (Pattisiana et al., 2010). Basically, cholesterol comes from lipid absorption inside the digestive tract and fatty acid metabolism in the fish liver (Di Marco et al., 2008). Cholesterol is divided into low-density lipoprotein (LDL) and high-density lipoprotein
(HDL). LDL is considered as unhealthy cholesterol because it will cling on a blood vessel, while HDL is considered as harmless cholesterol because it takes back the cholesterol to the liver to be processed.

Triglycerides are one of blood lipid in various body organ and it is used during the reproduction phase (Wahyuningsih et al., 2012). According to Mukhopadhyay and Ghosh (2007), the triglyceride is a major energy source in the fish body, both in liver and yolk-sac. Various concentration of triglycerides can be used as an indicator of the reproduction phase (Kocaman et al., 2005). The concentration of triglycerides shows lipid flow from the liver to fulfill a massive energy requirement during vitellogenesis process (Hachero-Cruzado et al., 2007).

Blood glucose is one of the essential carbohydrates as the main energy source to assist cell metabolism (Putri et al., 2013). The blood glucose concentration depend on several factors, such as age, size, nutrition requirement, and reproduction (Yousefian et al., 2010). Frequently, glucose is required continuously and has to be available in adequate concentrationin protein plasma. In the reproduction process, the protein plasma content depend on nutrition supply, so that both hormone and turmeric was used in this study to maintain the protein plasma.

The protein plasma concentration is related to vitellogenesis process. When spawning occurred, the protein plasma concentration will decrease (Saxena, 2002). Glycogen is a glucose deposit in most of the fish organ, especially hepatopancreas, flesh, or muscle (Akbar et al., 2011). Glycogen is stored as glucose inventory and act as highenergy phosphate manufacturer (Effendi, 2016).

Information on biochemistry during fish maturation is highly required in fish reproduction study, notably that diversity affected by species, age, maturation, and broodstock condition. Therefore, in this study, various biochemistry parameters were examined, such as glucose concentration, cholesterol, triglyceride, HDL, LDL, and protein plasma. This study addressed to find biochemistry changes in striped catfish that fed using enhanced feed (PMSG, anti-dopamine, and turmeric).

\section{MATERIALS AND METHODS}

\section{Experimental design}

This study was conducted during low rainfall and dry season. The temperature was ranged from $31.4-34.9^{\circ} \mathrm{C}$ and $\mathrm{pH}$ 6.47. This study was 
designed using two treatments, i.e. control (K) and $\mathrm{HKu}$ treatmens (PMSG + anti-dopamine treatments and added with turmeric). The PMSG, anti-dopamine, and turmeric were added through the commercial feed with $30 \%$ of protein content. The experimental hormone premix was PMSG and anti-dopamine in dosage

$0.25 \mathrm{~mL}$ and $0.1 \mathrm{mg}$ per $\mathrm{kg}$, while turmeric flour was in dosage of $480 \mathrm{mg} / 100 \mathrm{~g}$. The commercial feed was weighed based on $3 \%$ of feeding rate. As many of $700 \mathrm{~mL}$ of egg-white was mixed with $200 \mathrm{~mL}$ of water. The turmeric flour was blended with $0.25 \mathrm{~mL} / \mathrm{kg}$ of PMSG and $0.1 \mathrm{~mL}$ of anti-dopamine. The mixture was then mixed together with egg-white. Furthermore, the mixture was added to the experimental feed and mixed up well. Lastly, the experimental feed was dried in temperature of $40^{\circ} \mathrm{C}$ for 24 hours. Finally, when the experimental feed was ready, those were put in a plastic container to keep it dry.

The experimental fish were fed twice a day using a feeding rate of $3 \%$, and sampling was conducted every two weeks. As many of 30 broodstocks were treated using the treatment with stocking density $1 \mathrm{fish} / \mathrm{m}^{2}$ for three months. The experimental broodstock in this study has spawned before and has no eggs. The broodstocks were reared in the earthen pond sized in $10 \times 20 \times 0.7 \mathrm{~m}^{3}$ and each treatment was separated using a net.

\section{Biochemistry observation}

\section{Blood chemistry analysis}

Glucose analysis was conducted using glucose liquicolor GOD-PAP kit. Cholesterol and lipoprotein (LDL and HDL) analysis were performed using the CHOD-PAP method.
Triglyceride was analyzed using enzymatic colorimetric method through CHPA-PAP commercial kit.

\section{Data analysis}

Blood biochemistry data was analyzed using least significant difference (LST test) if significant difference was detected. Chemical analysis was done descriptively. Data administration was conducted using Ms. Word 2007 and Minitab 16.

\section{RESULTS AND DISCUSSION}

\section{Result}

Biochemistry analysis

The blood chemistry parameters were cholesterol, triglyceride (TG), HDL, LDL, glucose, and total protein (Figure 1, 2 and 3). The cholesterol in control K treatment decreased straightly until $4^{\text {th }}$ sampling (284.14-180.73 mg/ $\mathrm{dL}$ ), while in TG increased until $3^{\text {rd }}$ sampling (473.77 $\mathrm{mg} / \mathrm{dL})$ and decreased on $4^{\text {th }}$ sampling. The HDL concentration decreased from $1^{\text {st }}$ sampling $(147.16 \mathrm{mg} / \mathrm{dL})$ until $4^{\text {th }}$ sampling (94.42 $\mathrm{mg} / \mathrm{dL}$ ). Unlike HDL, the LDL kept increasing from $1^{\text {st }}$ until $4^{\text {th }}$ sampling. The blood glucose content decreased from $1^{\text {st }}$ sampling to $4^{\text {th }}$ sampling.

Figure 2 described blood chemistry in striped catfish broodstock in $\mathrm{HKu}$ treatment. The cholesterol was quite stable from $1^{\text {st }}$ sampling to $4^{\text {th }}$ sampling $(248.48-282.48 \mathrm{mg} /$ dL). The triglyceride was relatively high on the $1^{\text {st }}$ sampling $(523.55 \mathrm{mg} / \mathrm{dL})$, then decreased on the $2^{\text {nd }}$ sampling and increased again on the $3^{\text {rd }}$ sampling until $4^{\text {th }}$ sampling $(307.77 \mathrm{mg} / \mathrm{dL})$. The

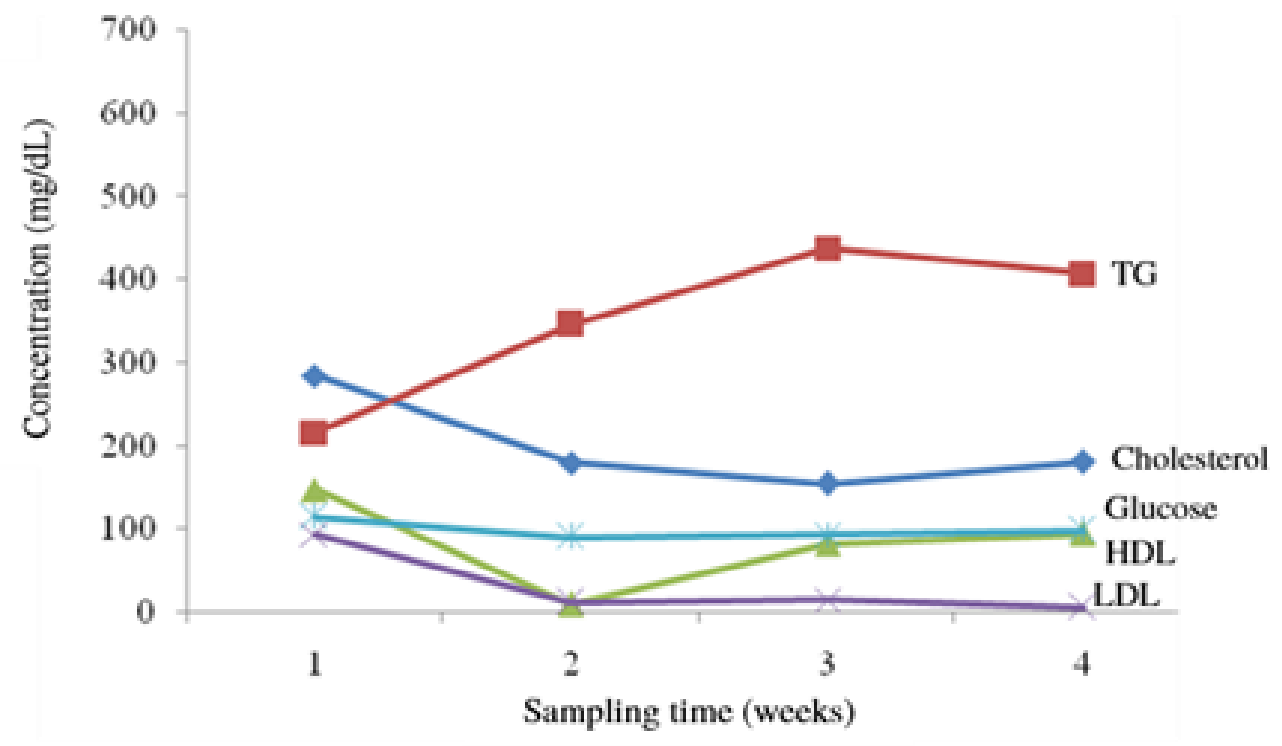

Figure 1. Blood chemistry of striped catfish broodstock in $\mathrm{K}$ treatment 


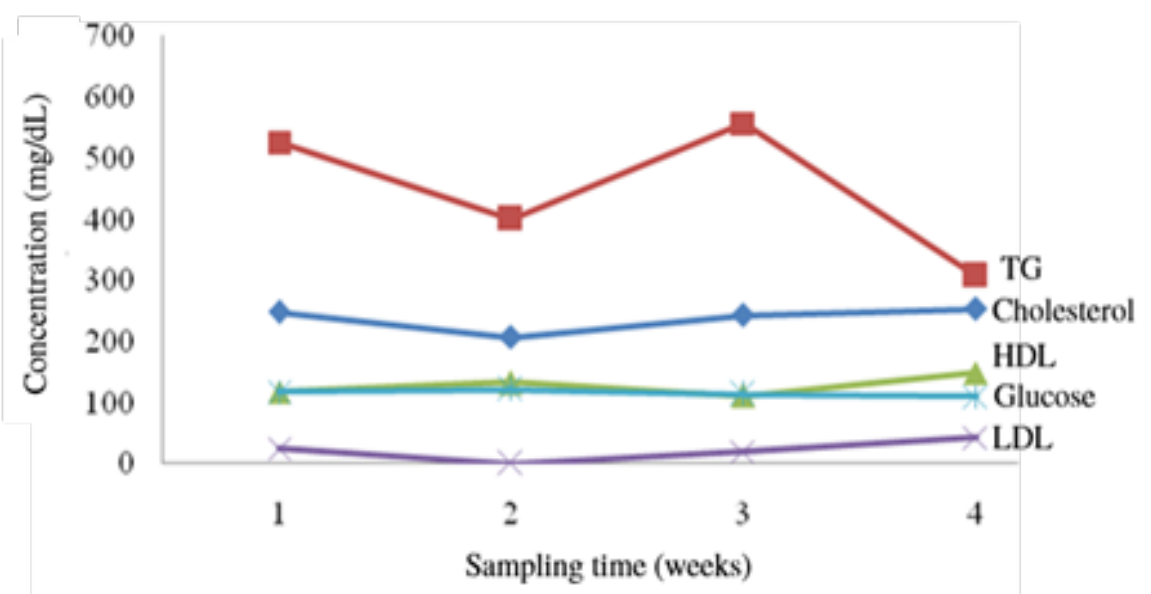

Figure 2. Blood chemistry of striped catfish broodstock treated with PMSG + anti-dopamine and added with turmeric through the diet.

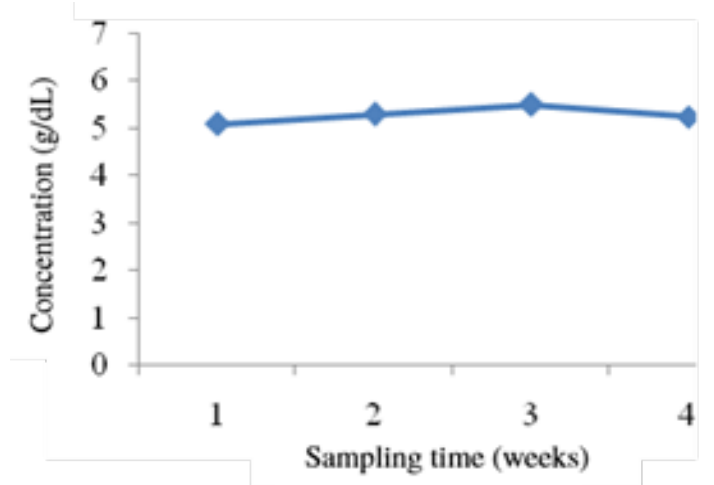

(A)

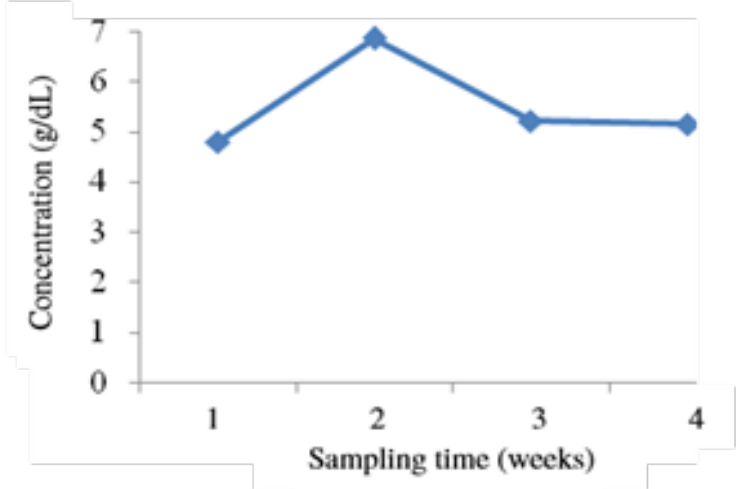

(B)

Figure 3. Total blood protein of striped catfish broodstock in control $\mathrm{K}(\mathrm{A})$, and $\mathrm{HKu}(\mathrm{B})$ treatments. HKu: fish treated with PMSG + anti-dopamine and added with turmeric through the diet.

Table 1. Glycogen content in striped catfish broodstock liver

\begin{tabular}{lcc}
\hline \multicolumn{1}{c}{ Sample code } & Water content $(\%)$ & Glycogen $(\mathrm{mg} / 100 \mathrm{~mL})$ \\
\hline Liver & & \\
Control (K) & 79.918 & 0.015 \\
Treatment (HKu) & 78.078 & 0.181 \\
\hline Flesh & & \\
Control (K) & 72.39 & 0.76 \\
Treatment (HKu) & 74.12 & 1.19 \\
\hline Gonad & & \\
Control (K) & 80.24 & 0.10 \\
Treatment (HKu) & 75.79 & 0.70 \\
\hline
\end{tabular}

HDL seemed to be stable on the $1^{\text {st }}(117.707 \mathrm{mg} /$ $\mathrm{dL})$, but it increased on the $4^{\text {th }}$ sampling $(148.83$ $\mathrm{mg} / \mathrm{dL})$. The LDL tended to decrease until $2^{\text {nd }}$ sampling, then it started to increase on the $3^{\text {rd }}$ and $4^{\text {th }}$ sampling $(42.55 \mathrm{mg} / \mathrm{dL})$. On the contrary, the blood glucose showed stable result through the experiment.

In the control treatment, the total blood protein in striped catfish broodstock remained stable on the $1^{\text {st }}$ sampling until $4^{\text {th }}$ sampling. In the $\mathrm{HKu}$ treatment, the total blood protein increased on the $2^{\text {nd }}$ sampling, but it went back to stable on the $3^{\text {rd }}$ sampling and $4^{\text {th }}$ sampling.

Liver glycogen, flesh, and gonad

The liver glycogen content is presented in Table 1 . In the $\mathrm{K}$ treatment, the liver glycogen $(0.015 \mathrm{mg} / 100 \mathrm{~mL})$ was lower than the $\mathrm{HKu}$ treatment $(0.181 \mathrm{mg} / 100 \mathrm{~mL})$. Both flesh and gonad of striped catfish broodstock in $\mathrm{HKu}$ treatment showed higher glycogen content. 


\section{Discussion}

The experimental broodstock were reared in low stocking density $\left(15 \mathrm{ind} / \mathrm{m}^{2}\right)$, thus stress condition could be avoided. It is related to physiological and biochemistry of the broodstock (Gaber et al., 2012). Cholesterol is a lipid and triglyceride at the same time that plays essential role both in energy source and reproduction. The blood plasma showed various result each treatment. The cholesterol increased on the $3^{\text {rd }}$ and $4^{\text {th }}$ week in $\mathrm{HKu}$ treatment. It triggered estradiol (PMSG) increased from the beginning of the study until the $4^{\text {th }}$ week. Increasing blood plasma estradiol indiceted that the vitellogenesis process was occurring and the value of cholesterol was affected by curcumin compound in turmeric.

Curcumin acts as cholesterol-7 $\alpha$-hydroxylase enzyme stimulation (El-Wakf et al., 2011). The enzyme is located in the liver cell and it potentially increases blood cholesterol. Cholesterol in blood will be modified to bile salt and several parts of it will be utilized in steroid hormone secretion (Fitriyah et al., 2008). Arifin (2015) reported that turmeric extract addition boosted cholesterol in Osphronemus goramy. Cholesterol is a precursor for steroid synthesis and it will affect gonadal maturation (Hiramatsu et al., 2015) so that the escalation of cholesterol was followed by estradiol. In this study, the greatest increase of cholesterol occurred before spawning and it returned to be low right after spawning.

The diversity of cholesterol and triglyceride is profoundly affected by the reproduction phase. In this study, $\mathrm{HKu}$ treatment apparently affected cholesterol and triglyceride. According to Cheng et al. (2006), cholesterol and triglyceride content of feed also showed a positive result in grouper Epinephelus coioides. Broodstock feeding with a high amount of lipid and a similar amount of protein will cause cholesterol and triglyceride higher than using a high amount of protein, but a similar amount of lipid.

The increase of cholesterol and triglyceride was affected by HKu treatment. This indicated that the broodstocks were undergoing vitellogenesis and cholesterol decreased after oocyte maturation phase. This process was important for female broodstock. The enlarged liver implied that the liver also had a role to synthesis vitellogenin. Estradiol-17 $\beta$ will spread in the liver and diffused into body tissues and induced the liver to produce vitellogenin (Hana et al., 2016).

At the end of sampling, the HDL increased in HKu treatment. A similar result was also obtained by Javed and Usman (2015) in Channa punctatus.
The concentration of protein plasma always related to the fluctuation of vitellogenin in catfish broodstock. The decreasing of protein plasma during spawning also happened in Channa spp. (Saxena, 2002). A similar result also occurred in this study, but on the other hand, there was no protein plasma changes in $\mathrm{K}$ treatment.

The glycogen content was also measured in the experimental broodstock. Glycogen is another deposit form of glucose, located in almost most body tissues, such as liver, flesh, and gonad. The experiment result showed that glycogen content in HKu treatment was higher than in the K treatment. The stored glycogen in a fish body was able to be transformed into glucose as an energy source. The result described that the treated broodstock underwent gonadal maturation faster than no treated broodstock. It is explained that $\mathrm{HKu}$ treatment was able to increase liver performance and nutrient metabolism. The outcome would be utilized as yolk material, so that follicle development would be higher compared to control treatment.

\section{CONCLUSION}

The changes in blood plasma and glycogen presented significant result between treatments. The spawning pattern of broodstock between treatments was described clearly in treated broodstock. Glycogen in liver tissues, flesh, and gonad in treated broodstock showed greater result in fish treated with PMSG + anti-dopamine and turmeric through the diet than non treated broodstocks.

\section{REFERENCES}

Ahlina HF, Sudrajat AO, Budiardi T, Affandi R. 2015. Hormonally induced gonadal maturation in eels, Anguilla bicolor bicolor (McClelland, 1984) with the use of pregnant mare serum gonadotropin, anti-dopamine, and recombinant growth hormone. Jurnal Ikhtiologi Indonesia 15: 209-22.

Alinezhad V, Alinezhad H, Ataee R, Ataie A. 2017. Utilization of curcumin and nanocurcumine compounds in cancer therapy. Pharmaceutical and Biomedical Research 3: 1-11.

Akbar J, Adriani M, Aisiah S. 2011. The effect of contains chromium $\left(\mathrm{Cr}^{3+}\right)$ at various levels of salinity on the growth of climbing perch Anabas testudineus. Bionatura-Jurnal IlmuIlmu Hayati dan Fisik 13: 248-254. 
Arifin PP. 2015. Evaluation of the addition of turmeric Curcuma longa Linn. extract in diet for digestive enzymes and growth performance of gouramy Osphronemus gouramy. [Thesis]. Bogor: Graduate School of Bogor Agricultural University.

Arfah H, Sudrajat AO, Supriyadi MA, Zairin M. 2018. Gonadmaturationoffemalestriped catfish Pangasionodon hypophthalmus (Sauvage, 1878) using a combination of pregnant mare serum gonadotropin+antidopamine, vitamin E, and curcumin extract mixed feed outside its spawning season. International Journal of Fisheries and Aquatic Studies 6: 52-57.

Calado SR, Gardner RT, Carnevali O "Growout and Broodstock Nutrition", in Marine Ornamental Species Aquaculture. John Wiley \& Sons, 2017, Chapter 10.

Cheng AC, Chen CY, Liou CH, Chang CF. 2006. Effects of dietary protein and lipids on blood parameters and superoxide anion production in the grouper, Epinephelus coioides (Serranidae: Ephinephelinae). Zoological Studies 45: 492-502.

Di Marco P, Priori A, Finoia M G, Massari A, Mandich A, Marino G. 2008. Physiological responses of European sea bass Dicentrarchus labrax to different stocking densities and acute stress challenge. Aquaculture 275: 319-328.

Effendi I. 2016. Intensive culture of white shrimp Litopenaeus vannamei in sea net cage: location, physiological, and biochemical studies. [Dissertation]. Bogor: Graduate School of Bogor Agricultural University.

El-Wakf AM, Elhabiby EM, El-kholy WM, ElGhany. 2011. Use of turmeric and curcumin to alleviate adverse reproductive outcomes of water nitrate pollution in male rats. Nature and Science 9: 229-239.

Fitriyah A, Wihandoyo, Supadmo, Ismaya. 2008. Blood plasma hormone testosterone level and sperm quails Coturnix coturnix japonica quality after given lemuru fish and palm oil. Animal Production 10: 157-163.

Forlano P. 2017. Evidence for dopaminergic forebrain neurons as modulators of seasonal peripheral auditory sensitivity in a vocal fish. Journal of the Acoustical Society of America 141: 3860.

Gaber MM, Omar EA, Abdel-Rahim M, Nour AM, Zaki MA, Srour TM. 2012. Effects of stocking density and water exchange rates on growth performance of tiger shrimp, Penaeus semisulcatus cultured in earthen ponds.
Journal Aquaculture Research Development 3: $1-5$.

Hachero-Cruzado I, García-López Á, Herrera M, Vargas-Chacoff L, Martínez-Rodríguez G, Mancera JM, Navas JI. 2007. Reproductive performance and seasonal plasma sex steroid and metabolite levels in a captive wild broodstock of brill Scophthalmus rhombus

L. Aquaculture Research 38: 1161-1174.

Hara A, Hiramatsu N, Fujita T. 2016. Vitellogenesis and choriogenesis in fishes. Fish Science.

82: 187-202.

Hiramatsu N, Todo T, Sullivan C, Schillin J, Reading BJ, Matsubara T, Ryu Y, Mizuta H, Luo W, Nishimiya O, Wu M, Mushirobira Y, Yilmaz A, Hara A. 2015. Ovarian yolk formation in fishes: Molecular mechanisms underlying formation of lipid droplets and vitellogenin- derived yolk proteins. General and Comparative Endocrinology 221: 9-15.

Hwa-Young L, Seung-Wook K, Geum-Hwa L, Min-Kyung C, Han-Wool J, Young-Jun K, Ho- Jeong K, Han-Jung C. 2016. Turmeric extract and its active compound, curcumin, protect against chronic CCl4-induced liver damage by enhancing antioxidation. BMC Complementary and Alternative Medicine 16: 316.

Islami MF, Sudrajat AO, Carman O. 2017. Induction of maturation and ovulation of red fin shark fish Epalzeorhynchos frenatus in non-spawning season. Journal of Fisheries and Aquatic Studies 5: 418-424.

Javed M, Usmani N. 2015. Stress response of biomolecules (carbohydrate, protein and lipid profiles) in fish Channa punctatus inhabiting river polluted by thermal power plant effluent. Saudi Journal of Biological Sciences 22: 237-242.

Kabir MA, Alireza G, Roshada H. 2012. Ovarian development and sexual maturation of female striped catfish, Pangasianodon hypophthalmus (Sauvage, 1878) reared in captivity. Asian Fisheries Science 25: 232-244.

Kocaman EM, Yanik T, Erdogan O, Ciltas AK. 2005. Alteration in cholesterol, glucose and triglyceride levels in reproduction of rainbow trout Oncorhynchus mykiss. Journal of Animal and Veterinary Advances 4: 801-804.

Kyung EJ, Kim HB, Hwang ES, Lee S, Choi BK, Kim JW, Kim HJ, Lim SM, Kwoin OI, Woo EJ. 2018. Evaluation of hepatoprotective effect of curcumin on liver cirrhosis using 
a combination of biochemical analysis and magnetic resonance-based electrical conductivity imaging. Mediators of Inflammation 2018: 1-9.

Mahmoud MMA, El-Lamie MMM, Dessouki AA, Yusuf MS. 2014. Effect of turmeric Curcuma longa supplementation on growth performance, feed utilization, and resistance of Nile tilapia Oreochromis niloticus to Pseudomonas fluorescens challenge. Journal of Fishery Science and Aquaculture 1: 026-033.

Mukhopadhyay T, Ghosh S. 2007. Lipid profile and fatty acid composition of two silurid fish eggs. Journal of Oleo Science 56: 399-403.

Nugraha AD. 2014. Gonad maturation of striped catfish, Pangasianodon hypophthalmus using OODEV through feed for 4 weeks at interval of 1 week. [Undergraduate thesis]. Bogor: Bogor Agricultural University.

Pattiasina BJ, Junior MZ, Mokoginta I, Affandi R, Manalu W. 2010. Ovarian development of female mud crab, Scylla serrata supplemented with cholesterol and injected with serotonin. Jurnal Akuakultur Indonesia 9: 67-76.

Podhorec P, Gosiewski G, Ammar IB, SokolowskaMikolajczyk M, Chyb J, Milla S, Boryshpolets S, Rodina M, Linhartova Z, Biro D, Stejskal V, Kouril J. 2016. The effect of GnRHa with or without dopamine inhibitor on reproductive hormone levels and sperm quality in tench, Tinca tinca. Aquaculture 470: 91-94.

Polipoch S, Punsawad C, Koomhin P, Suwannalert P. 2014. Hepatoprotective effect of curcumin and alpha-tocopherol against cisplatininduced oxidative stress. BMC Complement Alternative Medicine 14: 111-119.

Saxena A. 2002. Biochemical changes in blood of Channa sp. Indian Journal of Animal 36: 22-26.

Shankar DS, Kulkarni RS. 2007. Tissue cholesterol and serum cortisol level during different reproductive phases of female freshwater fish
Notopterus notopterus (Pallas). Journal of Environmental Biology 28: 137-139.

Sharaf SM. 2011. Effect of GnRH, pimozide, and ovaprime on ovulation and plasma sex steroid hormones in African catfish, Clarias gariepiunus. Journal Animal Production and Fish 77: 1709-1716.

Sinjal H, Ibo F, Pangkey H. 2014. Evaluasi kombinasi pakan dan estradiol $17 \beta$ terhadap pematangan gonad dan kualitas telur ikan lele dumbo Clarias gariepinus. Jurnal LPPM Bidang Sains dan Teknologi 1: 97-112.

Sudrajat AO, Sugati A, Alimuddin. 2014. Induced maturation of eel Anguilla bicolor using different hormone combination. Jurnal Akuakultur Indonesia 12: 189-201.

Tahapari E, Dewi RRSPS. 2013. Reproduction improvement on female striped catfish Pangasianodon hypophthalmus at dry season by hormonal induction. Berita Biologi 12: 203-209.

Thongon N, Boonmuen N, Suksen K, Wichit P, Charingoudua A, Tuchinda P, Suksamrarn A, Winuthayanon W, Piyachaturawat P. 2017. Selective estrogen receptor modulator (SERM)-like activities of diarylheptanoid, a phytoestrogen from Curcuma comosa, in breast cancer cells, pre-osteoblast cells, and rat uterine tissues. Journal of Agricultural and Food Chemistry 65: 3490-3496.

Wahyuningsih H, Junior MZ, Sudrajat AO, Tumbelaka LI, Manalu W. 2012. Changes of blood plasma and gonadal maturity on female Tor soro in pond. Jurnal Iktiologi Indonesia 12: 25-34.

Yousefian M, Amiri MS, Hedayatifard M, Dehpour AA, Fazli H, Ghiaci M, Farabi SV, Nahafpour SH. 2010. Serum biochemical parameter of male and female rainbow trout Oncorhynchus mykiss cultured in Haraz River, Iran. World Journal of Fish and Marine Sciences 2: 513-518. 